\title{
Compromising (on) the general conditionality mechanism and the rule of law
}

There was a sigh of relief at the European Council meeting, in December 2020. ${ }^{1}$ After weeks of uncertainty, the Hungarian and Polish governments were persuaded not to veto the adoption of the new EU financial package. The Multiannual Financial Framework (MFF) and the "Next Generation EU" (NGEU) instrument were seemingly saved; the recovery of COVID19afflicted Europe could finally begin. The way the settlement was reached is, however, less cause for celebration.

\section{The background}

The origin of the two governments' ire was not the financial arrangement itself: the two countries are likely to be among the biggest beneficiaries of the transfers it envisages. The roots of their displeasure are to be found in the European Commission's proposal, subsequently supported by other Member States and the Parliament, to introduce a mechanism that would subject the allocation of EU funds to the recipients' observance of the principles of the rule of law. ${ }^{2}$ While the notion that EU money should be spent in accordance with various conditions is not new, it gained further traction in the post-Brexit negotiations of the new MFF and the hesitancy of the so-called "frugals" to increase their contribution, but also against the backdrop of further deterioration of the rule of law in several EU countries, ${ }^{3}$ and growing indications that EU money may have helped sustain those problematic regimes. ${ }^{4}$

Aware that the proposed conditionality mechanism could affect their access to EU funds, ${ }^{5}$ and given the latter's critical significance for their economies, the Hungarian and Polish governments were intent on preventing its adoption. Their campaign started almost immediately after the publication of the Commission's proposal. But it came to a head after the European Council, at its marathon meeting of July 2020, blessed both the linkage between EU spending and the rule of law, and the establishment of a conditionality mechanism to that

\footnotetext{
${ }^{1}<$ www.irishtimes.com/news/world/europe/cheers-and-jeers-as-poland-and-hungary-lift-veto-on-eu-funds$1.4434424>$.

${ }^{2}$ Proposal for a Regulation of the European Parliament and of the Council on the protection of the Union's budget in case of generalised deficiencies as regards the rule of law in the Member States, COM(2018)324; based on Article 322(1)(a) TFEU, and Article 106a EAEC.

${ }^{3}$ De Gruyter, "A fundamental fight: The frugal four and the rule of law" <ecfr.eu/article/a-fundamental-fightthe-frugal-four-and-the-rule-of-law/>.

${ }^{4}$ Kelemen, “The European Union's authoritarian equilibrium”, 27 Journal of European Public Policy (2020), 481-499.

${ }^{5}$ EEA funding to Hungary and Poland have been suspended in the past as a result of the countries' failure to comply with conditions enshrined in the EEA protocol, <euobserver.com/nordic/137726>; Holmøyvik, "For Norway it's official: The rule of law is no more in Poland", VerfBlog, 29 Feb. 2020.
} 
effect. ${ }^{6}$ The latter was in fact a conditio sine qua non for the frugals to agree on the historic financial arrangement.

The Hungarian and Polish Prime Ministers then tried to water down the terms of the envisaged mechanism. Attempts were made to have its modalities discussed and agreed at the European Council itself, thus pre-empting the normal law-making process to adopt the Regulation, including the use of QMV in Council and the risk of being out-voted. Circulated drafts of the conclusions of the July 2020 meeting testify the degree to which efforts were made, notably by the Hungarian Prime Minister, drastically to circumscribe the application of the mechanism. ${ }^{7}$ In the event, the conclusions of the July European Council remained somewhat general: underlining the importance of the EU financial interests and the respect for the rule of law, they mentioned that a conditionality mechanism would be set up. They nevertheless specified that measures proposed by the European Commission in the context of the mechanism, i.e. to suspend transfers to a Member State, would have to be adopted by the Council, using qualified majority, thus substituting the procedure initially proposed by the Commission to use reverse qualified majority - under which the Commission measure would be enacted unless opposed by a qualified majority of Member States. Lastly, the conclusions included an ambiguous formula whereby "The European Council will revert rapidly to the matter", 8 thus indicating further discussions at that level but without specifying their purpose.

The EU legislature subsequently worked on the Commission's proposal, and in consideration of the framework set out by the European Council in July. Taking account of concerns voiced at several stages of the process, ${ }^{9}$ the European Parliament and the Council eventually reached a compromise early November, opening the way for the Council's adoption of the Regulation by qualified majority. Unhappy with the compromise, the Hungarian and Polish Prime Ministers confirmed what they had threatened to do earlier, namely that they would veto the financial arrangements if they did not get what they wanted on the mechanism. In a joint statement following a bilateral meeting in Budapest, the two Prime Ministers declared that "the outcome of the negotiations between the Council Presidency and the European Parliament [did] not conform to the agreement reached among the Heads of State and Government at the July European Council". ${ }^{10}$ With a certain aplomb, they made clear their intention "to prevent a mechanism which would not strengthen, but undermine the Rule of Law within the Union by degrading it to a political instrument [adding that the] proposed conditionality circumvents the Treaty". They then asked "to limit the scope of any additional budgetary conditionality to the protection of the financial interests of the Union in accordance with the July conclusions of the European Council... to discuss in the European Council, whether a link between the Rule of Law and the financial interests of the Union should be established [and if so] to negotiate the necessary modification of the Treaties", through an intergovernmental conference. Building on their successful alliance to emasculate the

\footnotetext{
${ }^{6}$ Paras A24, 22-23, European Council Conclusions, 17-21 July 2020.

${ }^{7}<$ www.politico.eu/wp-content/uploads/2020/07/Hungary-text.jpg $>$.

${ }^{8}$ Para 23, European Council Conclusions, 17-21 July 2020.

${ }^{9}$ e.g. European Court of Auditors, Opinion No 1/2018 concerning the proposal of 2 May 2018 for a regulation of the European Parliament and of the Council on the protection of the Union's budget in case of generalised deficiencies as regards the rule of law in the Member States.

${ }^{10}<$ www.gov.pl/web/eu/joint-declaration-of-the-prime-minister-of-poland-and-the-prime-minister-of-hungary $>$.
} 
effectiveness of the procedure under Article 7 TEU, to which they remain subject, they also "decided to align [their] positions [so that] [n]either Poland, nor Hungary will accept any proposal that is deemed unacceptable by the other".

Unsurprisingly, the announcement caused bewilderment and frustration across the Union. As intended by the two Prime Ministers, it was now up to Member States and EU institutions to find a way not to imperil the launch of the hard fought and badly needed EU financial programmes. Given the pressure quickly to unlock the recovery funding, and warnings that it would be a mistake for the EU to cave in to blackmail, ${ }^{11}$ ways to bypass the vetoes were mooted. ${ }^{12}$ Some envisaged a recourse to the enhanced cooperation procedure, ${ }^{13}$ others suggested an intergovernmental treaty akin to the one agreed in 2012, after the UK had vetoed the proposed EU treaty change to reform the governance of the Eurozone. ${ }^{14}$

\section{The response}

Arguing in favour of maintaining the Union's cohesion, and in line with its "together for Europe's recovery" slogan, the German presidency of the Council opted for an arrangement $a$ 27. ${ }^{15}$ A way had to be found to make the two governments lift their veto, while establishing the Conditionality mechanism, in accordance with the July European Council agreement and on the basis of the November compromise of the Council and the EP. ${ }^{16}$ The Council presidency and the Commission president then engaged with the two recalcitrant governments behind closed doors, and cobbled together a deal that was subsequently submitted to, and endorsed by the European Council and the Commission, respectively.

Encapsulated in the first four paragraphs (amounting to three and half pages) of the European Council conclusions, ${ }^{17}$ the deal is meant to "constitute an appropriate and lasting response to the concerns expressed ... with regard to the draft Regulation... more particularly with regard to the way in which [it] will be applied." 18 This is not the place to give a thorough analysis of the deal, and how the latter specifically relates to, and possibly contrasts with, the substance of the (then draft) Regulation it is supposed to interpret. ${ }^{19}$ The following only provides a brief account of five key elements.

\footnotetext{
${ }^{11}<$ www.theguardian.com/commentisfree/2020/dec/10/for-europe-losing-britain-is-bad-keeping-hungary-andpoland-could-be-worse>; Poland and Hungary will be losers from a budget veto, Financial Times, 8 Dec. 2020.

${ }^{12}<$ www.euractiv.com/section/economy-jobs/news/eu-gives-24-hours-to-hungary-and-poland-to-lift-theirveto/>.

${ }^{13}<$ www.politico.eu/article/the-commission-proposes-eu-recovery-without-hungary-and-poland/>;

$<$ www.euractiv.com/section/economy-jobs/news/commission-considers-options-for-recovery-fund-withouthungary-and-poland/>.

${ }^{14}$ Treaty on Stability, Coordination and Governance in the Economic and Monetary Union (2012).

15“German EU Council Presidency insists on a 27-party solution on 2021-2027 MFF and Recovery Plan", Agence Europe, 8 Dec. 2020.

${ }^{16}<$ www.reuters.com/article/uk-eu-budget-germany-merkel/merkel-were-seeking-way-to-lift-poland-andhungarys-eu-veto-idUKKBN28J0Z8>.

${ }^{17}$ European Council, Conclusions, 11 Dec. 2020, paras 1-4.

${ }^{18}$ Ibid., paras. 1 and 4.

${ }^{19}$ Further on this, see e.g. <eulawlive.com/op-ed-rule-of-law-conditionality-as-interpreted-by-eu-leaders-byaleksejs-dimitrovs/>; <ecfr.eu/article/the-costs-of-merkels-surrender-to-hungarian-and-polish-extortion/>;
} 
First, the European Council recalled the principles that will govern the application of the mechanism. It started with a reminder that "the EU, its Member States and its institutions are all committed to promoting and respecting the values on which the Union is founded, including the rule of law". It then added that "Article 7 TEU establishes the procedure to address the breaches of the Union's values under Article 2 TEU" (emphases added), a formula that is more inspired by the joint declaration of the Hungarian and Polish Prime Ministers referred to earlier, ${ }^{20}$ than reflecting the law and the established case law of the European Court of Justice. ${ }^{21}$ As if this were needed, the conclusions further underscore that the application of the mechanism will be "objective, fair, impartial and fact-based, ensuring due process, nondiscrimination and equal treatment of Member States", and "in full respect of Article 4(2) TEU [and] the principle of conferral".

Second, further details are given as to the role, promoted by the two Prime Ministers, which the European Council itself is to play in the application of the Regulation, and specifically in relation to the potential Council decision to impose or lift the suspension measures proposed by the Commission. In particular, if requested by the Member State concerned by such measures, the European Council president will have no choice but to put the item on the agenda of the European Council, and the latter shall strive to formulate a common position on the matter. ${ }^{22}$ Resonating the July conclusions, and without an obvious legal basis in the Treaty allowing such a European Council role, ${ }^{23}$ a further attempt is thus made to introduce unanimity where the Regulation foresees qualified majority, and at the very least, include additional detours, transactions, and delays, in its application.

Third, and also in line with the joint declaration of the two Prime Ministers, ${ }^{24}$ the objectives and scope of application of the mechanism are strictly, even restrictively, defined. The Regulation is aimed "to protect the Union budget including the Next Generation EU, its sound financial management and the Union's financial interests", and thus to guard it "from any kind of fraud, corruption and conflict of interest". ${ }^{25}$ Its application is "subsidiary" in the sense that it will only be activated where other procedures set out in EU law do not allow the

Scheppele, Pech and Platon, "Compromising the Rule of Law while Compromising on the Rule of Law", VerfBlog, 13 Dec. 2020.

${ }^{20}$ Para 1 of the Joint declaration reads as follows: "We recall that the procedure for the protection of those values is stipulated by Article 7 of the Treaty."

${ }^{21}$ See e.g. Case C-64/16, Associação Sindical dos Juizes Portugueses, EU:C:2018:117; Case C-824/18, A.B. et al v. Krajowa Rada Sadownictwa, EU:C:2021:153, in which the ECJ has held that "Article 19 TEU ... gives concrete expression to the value of the rule of law stated in Article 2 TEU", thereby acknowledging that infringement proceedings can be launched against Member States violating their obligations flowing from these provisions. In the same vein, see Case C-502/19, Oriol Junqueras Vies, EU:C:2019:1115, where the ECJ held that "Article 10(1) TEU provides that the functioning of the Union is to be founded on the principle of representative democracy, which gives concrete form to the value of democracy referred to in Article 2 TEU". ${ }^{22} \mathrm{Cf}$. point 26 of the Preamble of the Regulation.

${ }^{23}$ Cf. Art. 15 TEU.

${ }^{24}$ See pt $6,2^{\text {nd }}$ sub. para. of the HU-PL Joint declaration.

${ }^{25} \mathrm{As}$ a result of this narrower focus, the mechanism could be activated more in relation to Member States affected by corruption, than to those breaching the rule of law; i.e. more towards Bulgaria, Romania, Czech Republic, Slovakia, Greece, Italy, Malta, than Poland, in view of a recent index of Transparency International: $<$ www.transparency.org/en/cpi/2020/table/pol>; <www.transparency.org/en/news/cpi-western-europe-and-eu>. 
Union budget to be protected more effectively, thereby limiting the Commission's discretion in deciding when to activate the mechanism. ${ }^{26}$

Fourth, and in the same vein, the European Council specified the method which the Commission has to follow in activating the mechanism. The "triggering factors established by the Regulation are to be read and applied as a closed list of homogeneous elements and not be open to factors or events of a different nature". Further weakening the linkage between the Regulation and the protection of the rule of law, the conclusions also stipulate that "the mere finding that a breach of the rule of law has taken place does not suffice to activate the mechanism". Instead, a "causal link between such breaches and the negative consequences on the Union's financial interests will have to be sufficiently direct and be duly established", 27 while measures to be proposed by the Commission will have to be "proportionate to the impact of the breaches of the rule of law on the sound management of the Union budget or... financial interests".

Last but not least, and this has been regarded as the most controversial element of the conclusions, the European Council indicated that in order to ensure respect for the principles governing the mechanism articulated in the deal, the Commission intends to develop and adopt guidelines, in close consultation with the Member States, on the way it will apply the Regulation, including a methodology for carrying out its assessment. It is also foreseen that such guidelines will be finalized after an eventual ECJ judgment, should an action for annulment be introduced with regard to the Regulation, adding that the Commission will not propose measures under the Regulation until such guidelines are finalized. Mention is also made of the "Commission's intention to adopt a Declaration, to be entered into the minutes of the Council deciding on the Regulation, expressing its commitment to apply the elements contained in [the relevant paragraphs of the conclusions], which fall within the remit of its responsibilities in the application of the Regulation".

In sum, the way found to persuade the Hungarian and Polish governments to lift their vetoes was to circumscribe the purpose and the potential application of the Regulation, specifically by toning down its connection with the rule of law - thereby endorsing what the two governments had striven to achieve at the European Council meeting in July. Moreover, and with the support of the Commission, the deal intends to delay the full activation of the mechanism not only by requiring that guidelines be first produced. With a touch a cynicism, it instrumentalizes a procedure before the ECJ to secure the rule of law in the EU, further to postpone the finalization of those critical guidelines and thus the full application of an instrument deemed to necessary for countering Member States' breaches of the rule of law impacting on the EU financial interests, while allowing the two Member States' access to fresh and significant EU funding in the meantime - which incidentally coincides with a pre-election period. ${ }^{28}$

\footnotetext{
${ }^{26}$ Discretion which is otherwise foreseen in Art 6(1) of the Conditionality Regulation.

${ }^{27} \mathrm{Cf}$. Art 4(1) of the Conditionality Regulation which mentions "breaches of the principles of the rule of law in a Member State [that] affect or seriously risk affecting the sound financial management of the Union budget or the protection of the financial interests of the Union in a sufficiently direct way" (emphasis added).

${ }^{28}$ The next parliamentary elections are due to take place in spring 2022 in Hungary (if not before), and in autumn 2023 in Poland (if not before).
} 
As could be expected, the two governments were satisfied with that deal. At a joint press conference in the context of the European Council December 2020 meeting, both praised the assurances the conclusions provided, even claiming that they gave them much stronger guarantees than they had two months and two weeks earlier. ${ }^{29}$ Slightly exuberant, the Hungarian Prime Minister called the compromise "the strongest possible instrument" because it is "above regulations", while the Polish Prime Minister explained that " $[\mathrm{t}]$ he conclusions are a permanent act of the ( sic) European law ... close to primary law ... close to the treaty. They're above regulations. Regulations can be changed ... but a regulation that has to be in line with these conclusions that we've adopted is not easy to change. It can only be changed if we change the conclusions in the future, and that requires unanimity". ${ }^{30}$

Other protagonists in the European Council ${ }^{31}$ and in the Commission ${ }^{32}$ seemed satisfied with the overall settlement too. The compromise was particularly welcomed by those (many) whose top priority was to secure the swift adoption of the financial package, without having recourse to an alternative arrangement à 25 that could have made things more complicated and time-consuming, and which incidentally could have diluted the "historic" character of the July 2020 decision, ${ }^{33}$ which some had referred to as the EU's Hamiltonian moment. ${ }^{34}$ Even the European Parliament, which was not taking part in the December transactions, ${ }^{35}$ and in particular those MEPs who had been closely involved in the negotiations of the Regulation with the Council, accepted the settlement despite some reservations. ${ }^{36}$ They were satisfied that the compromise could be adopted tel quel, and were given various reassurances by the Commission president that the application of the mechanism would not be delayed. ${ }^{37}$ Reacting

\footnotetext{
${ }^{29}<$ www.politico.eu/article/live-blog-eu-leaders-talk-coronavirus-climate-and-budget/\#1284842> . ${ }^{30} \mathrm{Ibid}$.

${ }^{31}$ At a press conference before the summit, the Dutch Prime Minister asked for three elements before supporting the deal: first, the European Parliament's views on the compromise; second, assurances from the Commission President that rule-of-law violations could be taken into account retroactively under the Regulation; and third, assurances based on an opinion of the Council legal service that the deal would not limit the operation and the scope of the conditionality regulation ( $<$ www.politico.eu/article/live-blog-eu-leaders-talk-coronavirus-climateand-budget/ $>$ ). In its brief opinion, the Council Legal Service affirmed, inter alia, that "Part I of the Conclusions of the European Council respects the content and objectives of the Regulation and is compatible with it. In particular, no element of Part I of the Conclusions is in conflict with the Regulation, contradicts it or amends it. It expresses a common understanding as referred to in paragraph 1. More generally, Part I of the Conclusions is in conformity with the EU Treaties and the principle of institutional balance. It respects the powers of the different institutions, including the power of the co-legislator to adopt the Regulation and the powers of the Commission and the Council to commit on how to apply it, in accordance with the Treaties. 13961/20, Brussels, 11 Dec. 2020.

${ }^{32}$ As confirmed by a subsequent "Commission statement", annexed to the Council note "Draft Regulation of the European Parliament and of the Council on a general regime of conditionality for the protection of the Union budget - Adoption of the Council's and of the statement of the Council's reasons; 14018/20, Brussels, 14 Dec. 2020 .

${ }^{33}<$ twitter.com/EmmanuelMacron/status/1337112011856109576?ref $\mathrm{src}=\mathrm{twsrc} \% 5 \mathrm{Etfw}>$.

${ }^{34}<$ www.liberation.fr/debats/2020/07/25/le-moment-hamiltonien-de-l-europe_1812359/>.

${ }^{35}<$ www.europarl.europa.eu/news/en/press-room/20201211IPR93622/parliament-approves-the-rule-of-lawconditionality-for-access-to-eu-funds $>$.

${ }^{36}$ European Parliament resolution of 17 Dec. 2020 on the Multiannual Financial Framework 2021-2027, the Interinstitutional Agreement, the EU Recovery Instrument and the Rule of Law Regulation (2020/2923(RSP). ${ }^{37}<$ ec.europa.eu/commission/presscorner/detail/en/speech_20_2442>.
} 
to various criticisms, and notably to the argument that its prerogatives had been encroached upon by the European Council, the EP legal service was asked to provide an opinion on the matter, in which it eventually suggested not to contest the deal before the ECJ, considering that it would likely be held inadmissible given that European Council conclusions are deemed not to have binding effect, and also because that confirmation could be politically inopportune.

So the veto threats were lifted, allowing the adoption of the new EU financial package, ${ }^{38}$ and that of the Conditionality Regulation, in the version agreed in November. ${ }^{39}$

\section{All's well that ends well?}

The conclusions of the European Council posited that the elements of the deal "constitute an appropriate and lasting response to the concerns expressed" (emphasis added). Various developments since the deal was sealed could suggest otherwise.

In a statement attached to the Council's first reading position on the Regulation, a few days after the deal, the Hungarian Government underlined that the "full implementation [of the arrangement] pertains to Hungary's vital national interests and is a precondition of Hungary's consent to any legislative act related to the multiannual financial framework for the years 2021 to 2027, including Next Generation EU". ${ }^{40}$ It thus made it explicit that further hostage-taking could well occur should the December deal not be fulfilled to its liking. With a two-thirds majority in parliament, the Hungarian ruling party could for instance derail the ratification of the EU "Own Resources" decision, ${ }^{41}$ which is required particularly for the full implementation of the NGEU mechanism (especially the ability for the Commission to borrow money). ${ }^{42}$

But, while the full implementation of the deal is a matter of "vital national interests", it is nevertheless not enough for the two governments which the other Member States and the Commission had sought to appease. Although the deal was deemed to have interpreted the Conditionality Regulation to respond to the concerns expressed, the Hungarian and Polish governments still voted against its adoption in Council. In a statement of reasons, the former explained that while the deal "addressed the political and some of the legal concerns of Hungary as regards the interpretation and application of the draft Regulation.... serious legal concerns remain as to the conformity of the draft Regulation with EU law that compel Hungary to vote against ...." 43

\footnotetext{
${ }^{38}$ Council Regulation (EU, Euratom) 2020/2093 of 17 Dec. 2020 laying down the multiannual financial framework for the years 2021 to 2027, O.J. 2020, L 433 I/11-22; Regulation (EU) 2021/241 of the European Parliament and of the Council establishing the Recovery and Resilience Facility, O.J. 2021, L 57/17-75.

${ }^{39}$ Regulation (EU, Euratom) 2020/2092 of the European Parliament and of the Council of 16 Dec. 2020 on a general regime of conditionality for the protection of the Union budget; O.J. 2020, L 433 I/1-10

${ }^{40}$ Draft Regulation of the European Parliament and of the Council on a general regime of conditionality for the protection of the Union budget - Adoption of the Council's position at first reading and of the statement of the Council's reasons; 14018/20, Brussels, 14 Dec. 2020.

${ }^{41}$ Council Decision (EU, Euratom) 2020/2053 of 14 Dec. 2020 on the system of own resources of the European Union and repealing Decision 2014/335/EU, Euratom, O.J. 2020, L 424.

${ }^{42}$ Para. A5, European Council Conclusions, 17-21 July 2020.

${ }^{43}$ Draft Regulation of the European Parliament and of the Council on a general regime of conditionality for the protection of the Union budget - Adoption of the Council's position at first reading and of the statement of the Council's reasons; 14018/20, Brussels, 14 Dec. 2020.
} 
Indeed, despite, or perhaps thanks to, the reassurances they obtained, the two governments are intending to turn to the ECJ to contest its legality, as they have indicated on several occasions and as explicitly acknowledged in the conclusions themselves, thereby activating the delaying mechanism enshrined therein. ${ }^{44}$ As playing for time is a key objective of the two governments' campaigns, they would wait until the very last moment of the twomonths deadline foreseen in Article 263(6) TFEU to activate the annulment procedure. ${ }^{45}$

Whether the mechanism can seamlessly operate once the guidelines are finalized, remains to be seen. The Polish Government, through its Justice minister, has already signalled its intention to ask the (overhauled) Polish "Constitutional Tribunal" (CT) for a ruling that the new rule-of-law mechanism attached to the EU budget is not in compliance with Poland's Constitution. ${ }^{46}$ It will be recalled that under the guidance of that minister, the CT has been the subject of far-reaching reforms that have significantly eroded its independence and upset its operation. ${ }^{47}$ At the time of writing, the request has not yet been formally made. One scenario may indeed be that the request will be made after the (potential) judgment of the ECJ on the legality of the Regulation. The Polish Government might thus question the authority of that ECJ judgment too, ${ }^{48}$ and ask the CT to follow the footsteps of the German Constitutional Court in Weiss. ${ }^{49}$ Although a CT decision to that effect would not, legally and practically, prevent the Commission proposing the suspension of funding, it could - judging from the restraint which observers have noticed in the Commission's use of the infringement procedure against Poland and Hungary ${ }^{50}$ - colour its readiness to do it, and/or the willingness of some members of the

\footnotetext{
${ }^{44}$ The two governments could have had difficulties in achieving such a suspension (of the application of the Regulation) through a request for interim measures in the form of an order of suspension in the context of their (potential) action for annulment against the Regulation as, arguably, the conditions for such interim measures would not be fulfilled here.

${ }^{45}$ Should the Court activate the expedited procedure, as the European Parliament and Commission suggested they would ask, one could expect a Court judgment by the end of 2021, thus postponing the full application of the Regulation to the early weeks/months of 2022.

${ }^{46}$ Taborowski, “In the EU, it's the Rule of Law. In Poland, it's Unconstitutional?”, VerfBlog, 1 Feb. 2021. ${ }^{47} \mathrm{See}$ in this respect the Commission's Reasoned Proposal in accordance with Article 7(1) of the Treaty on European Union regarding the rule of law in Poland; COM(2017)835 final; Commission's 2020 Rule of Law Report - Country Chapter on the rule of law situation in Poland, SWD(2020)320, 30 Sept. 2020. See also Sadurski, "Polish Constitutional Tribunal under PiS: From an activist court, to a paralysed tribunal, to a governmental enabler", 11 Hague J Rule Law (2019), 63-84.

${ }^{48}$ The Polish minister of Justice has repeatedly done so in relation to other ECJ decisions, for instance in reaction to the Court's judgment in Joined cases C-715, 718 \& 719/17, Commission v. Poland, Hungary and the Czech Republic, EU:C:2020:257: < notesfrompoland.com/2020/04/06/polish-minister-accuses-eu-of-trying-to-imposeforeign-culture-of-islam-on-us-following-ecj-ruling/; and to its ruling in Case C-824/18 A.B. et al., EU:C:2021:153: <ruleoflaw.pl/justice-minister-zbigniew-ziobro-on-the-cjeu-ruling-it-is-unacceptable-to-us/> . ${ }^{49}$ Judgment of 5 May 2020 - 2 BvR 859/15.

${ }^{50}$ See e.g. Pech, "Protecting Polish judges from Poland's Disciplinary 'Star Chamber': Commission v. Poland (Interim proceedings)”, 58 CML Rev. (2021),137-162; Scheppele, Kochenov and Grabowska-Moroz, "EU values are law, after all: Enforcing EU values through systemic infringement actions by the European Commission and the Member States of the European Union", 39 YEL (2021), 1-121; Kelemen, Pavone and Emmons, "The perils of passivity in the rule of law crisis: A response to von Bogdandy", VerfBlog, 26 Nov. 2019. See also Morijn, "Misjudging judges: The EU Commission's non-reply to a letter about judicial independence", VerfBlog, 3 March 2021.
} 
Council to support it; this would all ultimately contribute to further uncertainty, and ultimately disillusion about the mechanism.

Even if it were effective from day one, as submitted by the Commission president, the Regulation does not seem to be having the expected dissuasive effects. ${ }^{51}$ Since its adoption, and formal entry into force on 1 January 2021, the authorities in Budapest and Warsaw have actually doubled down on their belligerent agenda, adopting measures at odds with the rule of law and the very values that were recalled upfront by the European Council December 2020 conclusions. Thus, the persecution of judges has continued unabated, ${ }^{52}$ further corroding the EU legal order, ${ }^{53}$ as have assaults on free media, ${ }^{54}$ further undermining democracy and triggering international concerns that are profoundly damaging for the EU and its other Member States. ${ }^{55}$

While expecting all EU protagonists to respect the December arrangement in good faith, the two governments do not seem to feel any burden themselves with regard to the fulfilment of their part of the deal in terms of respecting the values of Article 2 TEU, let alone their obligation of sincere cooperation as Member States of the EU. Rather, and more generally, their defiant attitude towards common policy initiatives and interests, from climate, migration, to foreign policy or even vaccination, is becoming systematic, turning into an alternative approach to being an EU Member State.

Unfortunately, the way their veto threats were handled and partly rewarded with the December deal of the European Council and the Commission, and accepted by the European Parliament, vindicates this obstructionist behaviour, and may indeed inspire others outside Warsaw and Budapest to follow suit, as the Slovenian Prime Minister has signalled. ${ }^{56}$ In the meantime, the two States will be among the main beneficiaries of the EU financial transfers, putting the two governments in a position to use those for domestic political gains.

\section{A pyrrhic victory}

Let us finish these comments with three general observations (and some questions).

\footnotetext{
${ }^{51} \mathrm{Cf}$. <www.eppgroup.eu/newsroom/news/historic-result-rule-of-law-precondition-for-eu-funding >; Nguyen, "The EU's new rule of law mechanism - How it works and why the 'deal' did not weaken it" Hertie School Jacques Delors Centre Policy Brief, 17 Dec. 2020.

${ }^{52}<$ ruleoflaw.pl/first-president-of-the-supreme-court-tries-to-remove-judges-who-approached-the-cjeu/> .

${ }^{53}<$ www.politico.eu/article/dutch-court-escalates-rule-of-law-battle-with-poland/>.

${ }^{54}$ www.reuters.com/article/uk-polskapress-m-a-pknorlen/polands-pkn-orlen-to-buy-media-company-polskapress-idUKKBN28H1TX>; <ruleoflaw.pl/tvp-state-aid/>; Michnik, "Polish Democracy in the Crosshairs", Project Syndicate, 16 Feb. 2021; <www.dw.com/en/hungarys-opposition-klubradio-to-be-taken-off-the-air/a56514980>.

${ }^{55}$ Human Rights Commissioner of the Council of Europe deplores the silencing of Klubradio following the ruling of the Budapest Court: <twitter.com/CommissionerHR/status/1359105128524054529>;

$<$ www.state.gov/declining-media-pluralism-in-hungary/>; Assault on media freedom poses another test of EU's resolve, Financial Times, 16 Feb. 2021; <www.washingtonpost.com/opinions/global-opinions/poland-steps-upan-assault-on-free-expression-the-us-response-will-be-crucial/2021/02/16/44877f08-6d5c-11eb-ba56d7e2c8defa31_story.html>.

${ }^{56}<$ www.euractiv.com/section/all/news/slovenia-pm-backs-hungary-poland-in-eu-rule-of-law-row/>; $<$ www.politico.eu/article/slovenia-eu-presidency-council-calm-nerves-anze-logar/>.
} 
First, one may wonder whether the European Council and Commission's arrangement accommodating the two governments was worth the candle. As transpires from the brief account above, the deal may turn out to be more a quick fix than "an appropriate and lasting response" to all the concerns at hand. Also because that deal was unnecessary. In particular, there was no need to bring the European Council in the discussions on the draft Conditionality Regulation which was otherwise being handled by the EU institutional machinery. The Presidency did not have to hold up the ordinary legislative process, ${ }^{57}$ in which the EP and the Council had agreed on the text with 25 Member States in favour - i.e. far more than the required majority! Nor, a fortiori, was it necessary to tone down the instrument by reconfiguring the context in which it should be interpreted and applied, or to delay its full entry into force, to appease two recalcitrant governments.

The blackmail was allowed to function while it was avoidable in the first place. Departing from the majoritarianism they apply at home, the two governments demanded, and obtained, a variant of the Luxembourg compromise, whereby two national positions at odds with EU membership requirements ${ }^{58}$ were permitted to prevail over the interests of the Union, and a majority of the EU population. Ironically, this very behaviour, and the (successful) efforts to take a detour through the European Council to circumvent the normal EU decision-making process, offers a glaring demonstration of the two governments' contempt for the very functioning of the EU institutional framework based on checks and balances, and in turn for the rule of law in the EU more generally. That in itself was a reason not to cave into the blackmail.

Indeed, further possibility for the EU25 to emasculate the veto threats was there. ${ }^{59} \mathrm{~A}$ plan B had already been mooted in July when the Hungarian and Polish Prime Ministers threatened to use their veto. The card that the recovery plan may be agreed $a$ 25 could have been played much more decisively. Especially in view of the weak hand of the two governments, ${ }^{60}$ and as one of the latter's stance was seemingly faltering. ${ }^{61}$ Admittedly, an enhanced cooperation or an intergovernmental arrangement outside the Treaty framework would have been taxing, and time consuming, but the quick fix of December 2020 might prove to have made the relationship with those two governments even more taxing for the Union and more time-consuming in the longer run.

The other Member States and institutions may have thus missed a golden opportunity to confront the two recalcitrant governments. They had all the cards in their hands to call their bluff, and by the same token draw a line in the sand as to what is acceptable in the Union and what is not, the way they are otherwise so able to do in relation to candidates for accession.

This missed opportunity is all the more remarkable since, with the exception of France's empty chair crisis - which crippled the institutional framework for decades and from which

\footnotetext{
${ }^{57}$ Kelemen "Time to call Hungary and Poland's bluff", <www.politico.eu/article/time-to-call-hungary-andpolands-bluff/>.

${ }^{58} \mathrm{And}$ thus at odds with the majority of their populations, which remains overwhelming in favour of EU membership.

${ }^{59}$ Merler and Nicoli, "Beyond the veto of the EU Recovery Fund", VerfBlog, 27 Nov. 2020.

${ }^{60}$ Poland and Hungary will be losers from a budget veto, Financial Times, 8 Dec. 2020.

${ }^{61}<$ www.politico.eu/article/poland-eu-budget-compromise-jaroslaw-gowin-agreement/>;

$<$ www.dw.com/en/viktor-orban-hungary-will-stick-by-eu-budget-veto-threat/a-55819430>.
} 
lessons might have been learned - EU institutions and Member States have on occasion managed to resist such blackmail. The ability to say "no" to States' demands which may erode the integrity of the Union was forcefully demonstrated in 2011 in relation to the UK. ${ }^{62}$ Conversely, attempts to accommodate one or two Member States' extravagant wishes so as to keep them on board even at the expense of the EU foundational principles have not necessarily paid off, as the controversial 2016 deal with the UK demonstrates, as well as various previous attempts. ${ }^{63}$

The willingness to maintain the cohesion of the Union, coûte que coûte, may have been based on noble intentions. But it should not elude the necessary reckoning, based on a fundamental discussion about membership obligations that the current situation apparently requires. For what it is worth, the fact that the rule of law issue has now been raised to the highest political level in the EU may be a step in the right direction. Kicking the can down the road may produce the opposite effect to that of strengthening the cohesion and sustainability in the longer term. ${ }^{64}$

Second, the settlement itself, and the way it was reached, does beg questions about the role of the different protagonists, including the rotating presidency, in the EU decision-making process, and more broadly about the functioning of its institutional framework. The account given above shines a light on practices which, while followed in the interest of the Union and its Members (in casu, removing an obstacle to the unlocking of the essential financial package to kickstart the recovery of battered European economies), may paradoxically upset the functioning of the EU institutional framework, and ultimately the rule of law in the Union.

In particular, the conditionality incident epitomizes the disproportionally powerful role the European Council is left to play in the EU, and which casts a long shadow over the EU institutional framework. Admitting that the various crises the EU has gone through may justify a more prominent role for an institution that operates as the EU crisis-manager in chief, this evolution does not sit easily with the notion that, since the Treaty of Lisbon, the European Council has become a formal part of that institutional framework. As such, it is bound by the principles that govern the latter's functioning, chiefly the principle of institutional balance, which ultimately guarantee respect for the rule of law and democratic accountability in the EU decision-making process.

In this regard, one may regret that the European Parliament did not seize the opportunity to ask the ECJ to examine the content of the December deal. ${ }^{65}$ It could have provided an occasion for the Court to build on its limited case law regarding the European Council, ${ }^{66}$ and

\footnotetext{
62"Cameron frozen out after wielding veto", Financial Times, 9 Dec. 2011; $<$ blogs.lse.ac.uk/politicsandpolicy/victory-for-europe-disaster-for-britain/>

${ }^{63}$ Gardner, Constitutional Disintegration and Disruption. Withdrawal and Opt-Outs from the European Union (PhD thesis, EUI, July 2020).

${ }^{64}$ Münchau, "When the moral compass malfunctions", <www.eurointelligence.com/column/moral-compass>; see also in this regard Theuns, "Could we found a new EU without Hungary and Poland?", $<$ euobserver.com/opinion/149470>.

${ }^{65}$ In this regard, see Alemanno and Chamon: "To save the rule of law you must apparently break it", VerfBlog, 11 Dec. 2020.

${ }^{66}$ E.g. Case C-370/12, Pringle, EU:C:2012:756; Joined Cases C-208-210/17 P, NF et al., EU:C:2018:705; Joined Cases C-643 \& 647/15, Slovakia and Hungary v. Council EU:C:2017:63.
} 
further articulate the legal framework within which, as an EU institution, it is to operate. Legal scholarship too should pay more attention to that institution. The nature of its powers, exercised through an ever-expanding variety of activities and initiatives, but also the significance of its conclusions, their drafting and their impact, needs to be further studied and indeed monitored.

One specific issue in this context is the European Council's relationship with the Commission and the consequences this relationship has on the latter's responsibilities. The process leading to the December arrangement, and the Commission (president)'s involvement and support, raises questions about the degree to which the institution is as independent as Article 17 TEU requires it to be - and as its president emphasized before the European Parliament, following the December European Council. ${ }^{67}$ Can the president of the Commission disregard the conclusions or other initiatives of the European Council, to which s/he has been associated as member? Can the Commission "retain in the context of its participation in the activities [of the European Council] its role of guardian of the Treaties"? ${ }^{68}$

The double-hatting of the European Commission president therefore raises questions not only in the context of the Conditionality Regulation, but also about the discretion which the institution has traditionally enjoyed as Guardian of the Treaties, ${ }^{69}$ especially in the framework of the infringement procedure. ${ }^{70}$ The institutionalized relationship it entertains with the European Council, combined with the increased political profile it has developed both as result of Treaty reforms and policy developments, and allegedly to beef up its democratic legitimacy, beg questions about the way in which the Commission exercises its discretionary power. As mentioned above, the Commission has shown circumspection in its use of the infringement mechanism notably to address the rule of law deterioration in Hungary and Poland..$^{71}$ While this particular approach might be a legitimate exercise of that power, one may wonder whether the latter ought nevertheless to be scrutinized so as to guarantee that it does meet the Commission's Treaty-based obligation to "ensure the application of the Treaties, and of measures adopted by the institutions pursuant to them".

Indeed the Star Fruit case, ${ }^{72}$ which remains the authority to support the notion that "the Commission is not bound to commence infringement proceedings, but has a discretion in that respect", ${ }^{73}$ was not so much a case about the discretion of the Commission in general. Rather it concerns more specifically the question of whether private persons could force it to start infringement proceedings through the failure to act procedure. The European Parliament, which is not a private person, could thus ensure that the Commission scrupulously fulfils its

\footnotetext{
67" [T] he Commission will always act in full autonomy, full respect of the law and full objectivity", $<$ ec.europa.eu/commission/presscorner/detail/en/speech_20_2442>.

${ }^{68}$ In this respect, see Joined Cases C-597, 598, 603 \& 604/18 P, Dr. K. Chrysostomides et al. EU:C:2020:1028, para 96.

${ }^{69}$ Suggestions have indeed been made to split the Commission's powers:

$<$ www.faz.net/aktuell/wirtschaft/konjunktur/griechenland/griechenland-krise-schaeuble-will-eu-kommissionentmachten-13725683.html>; <euobserver.com/political/129799>.

${ }^{70}$ As recently recalled in Case C-575/18 P, Czech Republic v. Commission, EU:C:2020:530.

${ }^{71}$ See references supra note 48.

${ }^{72}$ Case C-247/87, Star Fruit, EU:C:1989:58.

${ }^{73}$ Case C-575/18 P, Czech Republic v. Commission, EU:C:2020:530
} 
obligations under Article 17(1) TEU. ${ }^{74}$ Such an obligation to act one the part of the Commission as Guardian of the Treaty might indeed be more constraining, and conversely the degree of its discretion whether or not to act might be more limited, in the context of the new conditionality mechanism. ${ }^{75}$ The guidelines that it is committed to adopt should thus make sure it does not (further) confine its capacity of action.

Third, the Conditionality Regulation itself is unlikely to be a game changer in the EU enforcement of the rule of law. ${ }^{76}$ Its restricted scope, its methodology, and its dependence on political support in the Council will make its contribution to compliance with good governance rather limited. As recalled above, not only has it not deterred the spreading deterioration of the rule of law, its tighter connection with the defence of the EU budgetary principles means that it is unlikely to help address many expressions of such regressions. Concretely, it will be difficult for the Commission to establish how the erosion of media freedoms, or assaults on women's rights impact on the EU financial interests in order to justify the suspension of funding.

That said, the Regulation could still play a useful role if ingeniously combined with other available instruments. Action to protect the rule of law and preserve the foundations of the EU more generally, should still be taken through other channels, and chiefly through a resolute and consistent recourse to the infringement procedure (Arts. 258-260), ${ }^{77}$ and, where appropriate, combined with requests for interim measures, and penalty payment to prevent, and hopefully reverse the decline in compliance. In this context, the Conditionality Regulation may play a useful role. Indeed, the various elaborations of the breaches of the rule of law which it codifies (e.g. in Art. 3) may help not only to activate the suspension of funding, but also to start infringement proceedings to address such breaches.

The EU Treaties have always comprised robust mechanisms to secure Member States' observance of Union norms. Enforcement, public and private, has indeed been a distinct feature of the EU legal order since its inception, and a key to its survival. Observance of those common norms, and the efficacy of their enforcement, presuppose respect for the rule of law. Posited as a value common to the Member States, it should continue to condition all the benefits of membership.

Christophe Hillion

March, 2021

\footnotetext{
${ }^{74}$ As indeed suggested at point 9 of its Motion for a Resolution to wind up the debate on the statements by the Council and the Commission pursuant to Rule 132(2) of the Rules of Procedure on the Multiannual Financial Framework 2021-2027, the Inter-Institutional Agreement, the EU Recovery Instrument and the Rule of Law Regulation (2020/2923(RSP), 14 Dec. 2020.

${ }^{75}$ As a budgetary authority and because the conditionality mechanism is after all about protecting the financial interests of the Union, the European Parliament has a particular responsibility to ensure that the Regulation operates as intended. This point is also made clear in Point 8 of the Motion for a Resolution (2020/2923(RSP), cited in the previous footnote. Further on the EP oversight: see Sanchez-Barrueco, "At the crossroads of a frozen conflict: Political oversight of the Council's administrative budget by the European Parliament", in this Review. ${ }^{76}$ Dimitrovs and Droste, “Conditionality Mechanism: What's In It?”, VerfBlog, 30 Dec. 2020;

$<$ eulawlive.com/op-ed-the-july-2020-special-european-council-the-eu-budgets-and-the-rule-of-law-reading-theeuropean-council-conclusions-in-their-legal-and-policy-context-by-john-morijn/> .

${ }^{77}<$ twitter.com/VeraJourova/status/1362358808266309635>.
} 